\title{
Contested disaster nationalism in the digital age: Emotional registers and geopolitical imaginaries in COVID-19 narratives on Chinese social media
}

\author{
Chenchen Zhang* (D) \\ School of History, Anthropology, Philosophy and Politics, Queen's University Belfast, United Kingdom \\ *Corresponding author. Email: chenchen.zhang@qub.ac.uk
}

(Received 18 June 2021; revised 27 November 2021; accepted 10 December 2021; first published online 6 January 2022)

\begin{abstract}
This article examines how affective narratives of the COVID-19 pandemic on Chinese social media reinforce and challenge established scripts of national identity, political legitimacy, and international geopolitical imaginary. Taking theoretical insights from the scholarship on trauma, disaster nationalism, and politics of emotions, I structure the analysis of social media posts from state media and private accounts around three emotional registers: grief as a crucial site of control and contestation during the initial stage of the outbreak; gandong (being moved in a positive way) associated with stories of heroic sacrifices, national unity, and mundane 'heart-warming' moments; and enmity in narratives of power struggles and ideological competition between China and 'the West', especially the United States. While state media has sought to transform the crisis into resources for strengthening national belonging and regime legitimacy through a digital reworking of the long-standing repertoire of disaster nationalism, alternative articulations of grief, rage, and vernacular memory that refuse to be incorporated into the 'correct collective memory' of a nationalised tragedy have persisted in digital space. Furthermore, the article explicates the ways in which popular narratives affectively reinscribe dominant ideas about the (inter)national community: such as the historical imagination of a continuous nationhood rising from disasters and humiliation, positive energy, and a dichotomous view of the international order characterised by Western hegemony and Chinese victimhood. The geopolitical narratives of the pandemic build on and exacerbate binary oppositions between China and 'the West' in the global imaginary, which are co-constructed through discursive practices on both sides in mutually reinforcing ways. The lens of emotion allows us to attend to the resonances and dissonances between official and popular narrativisations of the disaster without assuming a one-way determinate relationship between the two.
\end{abstract}

Keywords: Nationalism; COVID-19; China; Social Media; Emotion; Narratives

\section{Introduction}

Disasters and crises generate disruptions, uncertainties, and intense emotions that could potentially both threaten and reinforce the existing political order. In the aftermath of disastrous events, the narratives and practices commemorating, seeking to reckon with, or erasing the memory of them have important implications for shaping the collective identities and values of a political community. ${ }^{1}$ State actors may use rituals of commemoration and disaster discourse to restore social cohesion, reinforce political legitimacy, and mould collective memories that are central

\footnotetext{
${ }^{1}$ Emma Hutchison, Affective Communities in World Politics (Cambridge, UK: Cambridge University Press, 2016).

(c) The Author(s), 2022. Published by Cambridge University Press on behalf of the British International Studies Association. This is an Open Access article, distributed under the terms of the Creative Commons Attribution-NonCommercial-NoDerivatives licence (https://creativecommons.org/licenses/by-nc-nd/4.0/), which permits non-commercial re-use, distribution, and reproduction in any medium, provided the original work is unaltered and is properly cited. The written permission of Cambridge University Press must be obtained for commercial re-use or in order to create a derivative work.
} 
to the reproduction of national identity. ${ }^{2}$ However, as the literature on the politics of trauma and memory suggests, the encounters with traumatic events and the narrativisation of them afterwards are ambiguous, contradictory, and contentious. ${ }^{3}$ Ultimately, sovereign power cannot monopolise the ways in which lives are mourned or disasters are remembered despite its best attempts to do so.

The narratives of COVID-19 in Chinese cyberspace during and after the height of the outbreak have been tied up not only with questions of national identity and regime legitimacy, but also with the imaginary of international geopolitical rivalries. The different ways in which the pandemic has unfolded in different societies should be noted. While elsewhere it might have been a prolonged health crisis with alternate episodes of emergency situations and relative relaxations, the COVID-19 crisis in China from January to March in 2020 was a short period of intense emotions and social conflicts, ${ }^{4}$ which has then been followed by a long 'normalisation' (changtaihua) phase with an extremely low infection rate and guided by a 'zero-COVID' strategy. During the later phase and as the pandemic spread around the world, earlier emotionally laden debates focused on suffering, compassion, and government failures subdued, ${ }^{5}$ and a geopolitised discourse about the power and ideological competition between China and 'the West' became prominent. $^{6}$ What happened in the early months of 2020 has been remembered as a devastating disaster or a catastrophe. Scholars debate whether the term 'disaster' should refer to 'natural disasters' only or it should include 'human-generated' events with political and socioeconomic causes. ${ }^{7}$ Without seeking to define what intrinsic characteristics constitute a 'disaster', I use the term here to reflect the fact that the event has been represented and narrativised as such by the state and in public memory. Not only those who suffered it firsthand and those who watched the 'spectacle of suffering' from afar, primarily through social media, experienced the outbreak as a catastrophe, the Chinese state's responses have also deployed and expanded on long-standing disaster discourses around the theme of how 'disasters could regenerate a nation'.

Nationalism is not only discursive and institutional, but also affective and experiential. The nation needs to be constructed as both an 'object of our feeling' and a 'subject that has feelings'. The production of the citizen as an affective subject in relation to particular understandings of the national community and global politics relies on technologies of government that work on and through emotions. ${ }^{10}$ The affective-discursive composition of disaster nationalism on Chinese

\footnotetext{
${ }^{2}$ Mihai Stelian Rusu, 'Nations in black: Charting the national thanatopolitics of mourning across European countries', European Societies, 22:1 (2020), pp. 122-48; Bin Xu, 'Commemorating a difficult disaster: Naturalizing and denaturalizing the 2008 Sichuan earthquake in China', Memory Studies, 11:4 (2018), pp. 483-97.

${ }^{3}$ Jenny Edkins, Trauma and the Memory of Politics (Cambridge, UK: Cambridge University Press, 2003); Duncan Bell (eds), Memory, Trauma and World Politics: Reflections on the Relationship Between Past and Present (Basingstoke, UK: Palgrave Macmillan, 2006); Maja Zehfuss, Wounds of Memory: The Politics of War in Germany (Cambridge, UK: Cambridge University Press, 2007).

${ }^{4}$ Jiacheng Liu, 'From social drama to political performance: China's multi-front combat with the Covid-19 epidemic', Critical Asian Studies, 52:4 (2020), pp. 473-93.

${ }^{5}$ Online discontent has continued in a more sporadic fashion in the later phase of the pandemic, often focusing on grievances caused by harsh lockdowns and excessive restrictions during local flare-ups.

${ }^{6}$ I use quotation marks to refer to 'the West' as a historically contingent political, cultural, and racialised construct rather than a taken-for-granted geographical denomination. The quotation marks will be dropped hereafter for ease of readability.

${ }^{7} \mathrm{Bin} \mathrm{Xu}$, 'Commemorating a difficult disaster'.

${ }^{8}$ Duonan xingbang is a four-character idiom traced back to Zuo Zhuan, an ancient history book from the 4th century BC. It became popularised in contemporary disaster discourse after then Premier Wen Jiabao wrote down the phrase on a blackboard of Beichuan middle school during his visit after the 2008 Sichuan earthquake.

${ }^{9}$ Sara Ahmed, Cultural Politics of Emotion (Edinburgh, UK: Edinburgh University Press, 2014), p. 13; Jonathan Heaney, 'Emotions and nationalism: A reappraisal', in Nicolas Demertzis (eds), Emotions in Politics (Basingstoke, UK: Palgrave Macmillan, 2013), pp. 243-63.

${ }^{10}$ Anne Marie Fortier, 'Proximity by design? Affective citizenship and the management of unease', Citizenship Studies, 14:1 (2010), pp. 17-30; Mons Bissenbakker, 'Attachment required: The affective governmentality of marriage migration in the Danish aliens act 2000-2018', International Political Sociology, 13:2 (2019), pp. 181-97.
} 
social media is best approached in connection with emerging techniques of affective governance in digital space. These include both repressive censorship and what Peidong Yang and Lijun Tang name 'hegemonic interventions', or the encouragement and orientation of public expression towards building an affective atmosphere of 'positive energy'. ${ }^{11}$ However, the 'emotional bundling' that stories of suffering, love, sacrifice, and heroism, which are abundant in the pandemic times, induce is inherently ambivalent. ${ }^{12}$ Social media, despite increasingly restrictive means of control, allows a space for popular narratives to align with or contest dominant stories about the (inter)national community.

Taking theoretical insights from the scholarship on disaster nationalism and emotional politics, this article examines how affective narratives of the COVID-19 pandemic on Chinese social media reinforce and challenge established scripts of national identity, political legitimacy, and international geopolitical imaginary. The analysis is organised around three emotional registers or assemblages: grief was a critical site of control and contestation during the initial stage of the pandemic, namely when the 'catastrophe' occurred; gandong (being moved in a positive way), gratitude, and national pride have been mobilised by the state through representations featuring heroic sacrifices and mundane 'heart-warming' moments; enmity, antagonism, and contempt arose with regard to external and internal 'enemies' as the pandemic became entangled with great power competitions. While state media has sought to transform the crisis into resources for strengthening national belonging and regime legitimacy through a digital reworking of the long-standing repertoire of disaster nationalism, alternative expressions of grief, rage, and critical solidarity that refuse to be incorporated into the 'correct collective memory' of a nationalised and geopoliticised tragedy have persisted in online communities, even though they have been subject to silencing from the beginning and become much less visible in the later phase.

The research draws on interpretivist analyses of social media campaigns and 'viral' posts produced by state media and private accounts on Weibo, the biggest Chinese microblogging platform. The Weibo account of People's Daily, an official newspaper of the Central Committee of the Chinese Communist Party (CCP) with 132.4 million followers on the platform as of writing, is given special attention. Some of the materials referenced here are no longer available on the Internet due to censorship. I therefore have to refer to screenshots archived in anonymous, crowdsourced digital memory projects. This is complemented with everyday observation of digital interactions in the comment section of state media accounts and around relevant hashtags/topics.

This article updates the scholarship on disaster politics in China by offering a detailed account of how digitally mediated narratives of COVID-19 reproduce and question hegemonic imaginations of the national and international community. It also contributes to a burgeoning literature on emotions in world politics and on social media ${ }^{13}$ by attending to the affective resonances and dissonances between official and popular nationalism in China without assuming a dualistic or determinate relationship between the two. While the investigation here is focused on the Chinese case, the article joins a range of ongoing debates on how the pandemic has impacted on nationalist dynamics in both civic solidaristic and exclusionary forms around the world. Some of the developments examined here, such as the prevalence of militaristic metaphors, the outpouring of solidarity and gratitude, and the projection of fear onto foreign enemies, have been noted elsewhere - though inevitably played out differently across

\footnotetext{
${ }^{11}$ Peidong Yang and Lijun Tang, "Positive energy": Hegemonic intervention and online media discourse in China's Xi Jinping era', China: An International Journal, 16:1 (2018), pp. 1-22.

${ }^{12}$ Rebecca Adler-Nissen, Katrine Emilie Andersen, and Lene Hansen, 'Images, emotions, and international politics: The death of Alan Kurdi', Review of International Studies, 46:1 (2020), pp. 75-95.

${ }^{13}$ Roland Bleiker and Emma Hutchison, 'Fear no more: Emotions and world politics', Review of International Studies, 34: S1 (2008), pp. 115-35; Constance Duncombe, 'The politics of Twitter: Emotions and the power of social media', International Political Sociology, 13:4 (2019), pp. 409-29; Simon Koschut (eds), The Power of Emotions in World Politics (London, UK: Routledge, 2020).
} 
countries. ${ }^{14}$ Their manifestations in the Chinese context are shaped by the specific governing structures and strategies of nationalist mobilisation under which the image of the nation is bound up with authoritarian legitimation. ${ }^{15}$ Acknowledging similarities, local particularities, and interconnectedness in pandemic nationalisms offers an opportunity to think beyond the dominant geopolitical vision of global space divided into self-contained liberal/democratic and illiberal/autocratic territories, which is inadequate for accounting for complexity and the constitutive role of relations. ${ }^{16}$ Influenced by this dichotomous mapping, discussions of China in the international media, and to some degree in academic writings, tend to represent the country through an exceptionalist lens as an externalised authoritarian other of the West's liberal self, rather than an integral part of entangled global material and discursive conditions. ${ }^{17}$ In this respect, the geopolitical dimension of disaster nationalism explored in this article not only illustrates the inextricability between the domestic and the international, but also offers a perspective on the co-constitution of the China versus the West binary through essentialised narratives about self and other from both sides in mutually reinforcing ways.

I start by introducing the conceptual tools that inform this study and specifying the contexts of disaster nationalism and online affective governance in China. Engaging with the theoretical work on trauma, grief, and mourning, the first section examines the political significance of agonistic mourning and the state's efforts to control grievability. I then illustrate how state media mobilises the emotions of gandong and encourages an atmosphere of positive energy through adapting conventional scripts of disaster nationalism to the digital culture, not without unintended consequences. The third section investigates geopoliticised narratives of the pandemic that build on and intensify binary oppositions between China and the West in terms of power struggles and ideological competition. I conclude with reflections on the ambivalence of mediated memory politics.

\section{Disaster nationalism in digital times: Trauma, collective memory, and affective governance}

The idea of disaster nationalism underscores the role collective experiences and narratives of disasters play in the reproduction of dominant understandings of national identity and thereby legitimation of political orders. As Hakuki Eda has observed in the Japanese context, established nationalist ideologies help structure prevailing accounts of disasters, which in turn play a part in reinforcing these ideologies and delineating between the insiders and outsiders of the national community. ${ }^{18}$ The striking of a disastrous event often evokes intense emotions such as grief, fear, insecurity, compassion, and gratitude that could strengthen senses of belonging and national solidarity. J. Paul Goode, David R. Stroup, and Elizaveta Gaufman note that disruptive events such as the COVID-19 pandemic bring to the fore dynamics that usually go unnoticed in the

\footnotetext{
${ }^{14}$ See, for example, Florian Bieber, 'Global nationalism in times of the COVID-19 pandemic', Nationalities Papers, First View (2020), pp. 1-13; J. Paul Goode, David R. Stroup, and Elizaveta Gaufman, 'Everyday nationalism in unsettled times: In search of normality during pandemic', Nationalities Papers, First View (2020), pp. 1-25; Malcolm James and Sivamohan Valluvan, 'Coronavirus conjuncture: Nationalism and pandemic states', Sociology, 54:6 (2020), pp. 1238-50.

${ }^{15} \mathrm{~J}$. Paul Goode, 'Becoming banal: Incentivizing and monopolizing the nation in post-Soviet Russia', Ethnic and Racial Studies, 44:4 (2021), pp. 679-97.

${ }^{16}$ Natalie Koch, 'Post-triumphalist geopolitics: Liberal selves, authoritarian others', ACME: An International Journal for Critical Geographies, 18:4 (2019), pp. 909-24.

${ }^{17}$ For criticisms, see, for example, L. H. M. Ling, 'Worlds beyond Westphalia: Daoist dialectics and the "China threat"', Review of International Studies, 39:3 (2013), pp. 549-68; Pichamon Yeophantong and Chih-Yu Shih, 'A relational reflection on pandemic nationalism', Journal of Chinese Political Science, 0123456789 (2021).

${ }^{18}$ Hakuki Eda, 'Disaster justice: Mobilizing grassroots knowledge against disaster nationalism in Japan', in Andrew Jolivette (ed.), Research Justice: Methodologies for Social Change (Bristol, UK: Policy Press, 2015), pp. 95-108; Reiko Shindo, 'Enacting citizenship in a post-disaster situation: The response to the 2011 Great East Japan Earthquake', Citizenship Studies, 19:1 (2015), pp. 16-34.
} 
background in 'settled times'. This motivates everyday practices that seek to restore normality in 'unsettled times' through performing and consuming national solidarities. ${ }^{19}$ In the long term, the official commemoration of certain disasters - those involving socially 'meaningful loss' and that are recognised as 'collective tragedies ${ }^{\text {'20 }}$ - becomes ritualistic practices that reaffirm mainstream values and identities of the nation.

However, a disaster that takes lives and the traumatic experience it brings about are fundamentally unsettling. Jenny Edkins elaborates on the concept of 'trauma time', which is 'the time of the political' when settled stories are ruptured and the 'symbolism and ideology that concealed the fragile and contingent nature of authority collapse altogether', even if only briefly. ${ }^{21}$ Sovereign power, then, would take actions to 'close down any openings' by putting in place as fast as possible 'a linear narrative of origins' through, for instance, commemorative rituals. ${ }^{22}$ Despite the reinstallation of linear time, Edkins insists that trauma 'always intrudes' and 'cannot be completely forgotten'. ${ }^{23}$ She argues that the memory of catastrophic events is not only central to the operation of political power, but also to their contestation. Ways of remembering therefore is a crucial site of struggle in national and international politics.

In the Chinese context, the repertoire of disaster nationalism draws on both contemporaneous representations and historical imaginations, or a constant regeneration of collective memories of trauma and humiliation indispensable to the discursive construction of Chinese national identity. ${ }^{24}$ When a natural or man-made disaster strikes, the party state employs a well-established yet evolving template of political communication and emotional mobilisation to mourn the victims, celebrate heroic sacrifices, and highlight the unity and strength of the national community. ${ }^{25}$ The temporal dimension is crucial to the narration of the nation everywhere, and perhaps particularly so in Chinese disaster discourse, which constantly (re)calls into being a historical imaginary that frames the nation as rising from a traumatic past. As Prasenjit Duara puts it, the modern nation-state invents itself in a temporal disjunction between a linear history of progress and a peculiar timelessness from an imagined 'unchanging essence of the past'. ${ }^{26}$ In narrating national tragedies, the story therefore is not only about how the nation has overcome this particular disaster thanks to the heroic acts of the people and the leadership of the Party in the present, but also about reinventing the nation's seemingly timeless past: that she has always survived disasters. A commentary on People's Daily in the aftermath of the Sichuan earthquake epitomises this: 'The Chinese nation (zhonghua minzu) has suffered so many ordeals in its 5,000 years of history, but the blood lineage of the civilization has never been disrupted and the national history carried on. It is through encounters with each disaster that our nation has gained new spiritual resources continuously. ${ }^{27}$ As to be demonstrated below, the same framing is frequently employed in official and popular narratives of COVID-19. When it comes to the external dimension of disaster nationalism, the reanimation of victimhood identity underpinned by more recent

\footnotetext{
${ }^{19}$ Goode, Stroup, and Gaufman, 'Everyday nationalism'.

${ }^{20}$ Rusu, 'Nations in black'.

${ }^{21}$ Edkins, Trauma, pp. 12-13.

${ }^{22}$ Jenny Edkins, 'Remembering relationality: Trauma time and politics', in Bell (eds), Memory, pp. $99-115$ (p. 107).

${ }^{23}$ Edkins, Trauma, p. 16.

${ }^{24}$ Zheng Wang, Never Forget National Humiliation: Historical Memory in Chinese Politics and Foreign Relations (New York, NY: Columbia University Press, 2012); William A. Callahan, 'National insecurities: Humiliation, salvation, and Chinese nationalism', Alternatives, 29:2 (2004), pp. 199-218.

${ }^{25}$ Florian Schneider and Yih Jye Hwang, 'The Sichuan earthquake and the heavenly mandate: Legitimizing Chinese rule through disaster discourse', Journal of Contemporary China, 23:88 (2014), pp. 636-56; Chenchen Zhang, 'Covid-19 in China: From "Chernobyl moment” to impetus for nationalism', Made in China Journal, 5:2 (2020), pp. 162-5.

${ }^{26}$ Prasenjit Duara, 'The regime of authenticity: Timelessness, gender, and national history in Modern China', History and Theory, 37:3 (1998), pp. 287-308 (p. 290).

${ }^{27}$ Zhongping Ren, '凝聚起民族复兴的力量 [Gathering the strength of national rejuvenation]', People's Daily (4 July 2008). All translations are my own unless otherwise indicated.
} 
historical memories of 'national humiliation' becomes instrumental to emotional mobilisations against perceived international hostility.

The scholarship on the 2008 Sichuan Earthquake is worth a brief review here, as the event was of great importance in the genealogy of Chinese disaster nationalism and the responses share commonalities with the present case. As Bin Xu notes, the national mourning period introduced in the aftermath of the earthquake was the first in the history of the People's Republic China to mourn for ordinary victims of a disaster. He argues that this unprecedented mourning ritual enabled authorities to dramatise 'a paternalistic compassion' and perform a sympathetic moral state that cares in order to 'respond to societal challenges'. ${ }^{28}$ Similar to the state's attempt to monopolise the collective memory of COVID-19, while memorials have been built to 'remember', the state-orchestrated memory work creates a 'topography of forgetting' that excludes alternative interpretations of the earthquake. ${ }^{29} \mathrm{Xu}$ has also underscored the role of the mediated spectacle of suffering on television screens and the Internet in bringing forth heightened senses of compassion and national solidarity among the spectators. ${ }^{30}$ Furthermore, many of the themes highlighted by Florian Schneider and Yih Jye in their analysis of the disaster discourse around the earthquake have been recurrent in official and popular narratives of the epidemic crisis. These include, for example, the heroism of the People's Liberation Army soldiers (or 'white-clothed soldiers' in the case of COVID-19) who carried out the rescue operations, the resilience of the nation, and the superiority of the Chinese regime in 'placing lives above anything else'. ${ }^{31}$

Finally, this article integrates the literature on disasters, trauma, and memory politics with the debates on techniques of affective governance in Chinese cyberspace. While emotional mobilisation has always played a salient role in the CCP's ideological work since the Maoist era, ${ }^{32}$ evolving modes of governance in digital space have taken a more diffused and decentralised approach to fostering an atmosphere of 'positive energy' (zheng nengliang) that reconciles the tension between encouraging the expression of private desires and ideological control. ${ }^{33}$ Emerged first as a colloquial catchphrase on the Internet, 'positive energy' soon became incorporated into the official vocabulary in 2012. The concept resembles what Anne Marie Fortier calls a 'feel-good politics of cohesion' ${ }^{34}$ that gives more value to certain 'positive' emotions than 'negative' ones such as antagonism and anger. Rather than top-down communications of coherent political message seen in traditional propaganda, affective governance encourages netizens (wangmin) to freely and creatively express themselves as long as they are "transmitters of "positive energy" to create hopefulness and uplifting attitudes' ${ }^{35}$ However, this productive form of power complements rather than replaces the repressive power that 'kills emotions softly' either by labelling them as 'negative', 'uncivil', or 'irrational' or through direct censorship. ${ }^{36}$

\footnotetext{
${ }^{28} \mathrm{Bin} \mathrm{Xu}$, 'Moral performance and cultural governance in China: The compassionate politics of disasters', China Quarterly, 226 (2016), pp. 407-30.

${ }^{29} \mathrm{Xu}$, 'Commemorating a difficult disaster'.

${ }^{30} \mathrm{Bin} \mathrm{Xu}$, 'Durkheim in Sichuan: The earthquake, national solidarity, and the politics of small things', Social Psychology Quarterly, 72:1 (2009), pp. 5-8.

${ }^{31}$ Schneider and Hwang, 'The Sichuan earthquake'.

${ }^{32}$ Elizabeth Perry, 'Moving the masses: Emotion work in the Chinese Revolution', Mobilization: An International Quarterly, 7:2 (2002), pp. 111-28.

${ }^{33}$ Zifeng Chen and Clyde Yicheng Wang, "The discipline of happiness: The Foucauldian use of the "positive energy" discourse in China's ideological works', Journal of Current Chinese Affairs, 48:2 (2019), pp. 201-25. See also Angela Xiao Wu, 'The ambient politics of affective computing', Public Culture, 34:1 (forthcoming); Sheng Zou, 'Restyling propaganda: Popularized party press and the making of soft propaganda in China', Information, Communication and Society (2021), pp. 1-17.

${ }^{34}$ Fortier, 'Proximity by design'.

${ }^{35}$ Yang and Tang, 'Postive energy', p. 14.

${ }^{36}$ Guobin Yang, 'Killing emotions softly: The civilizing process of online emotional mobilization', Communication \& Society, 40 (2017), pp. 75-104.
} 
The politics of affect also offers critical insights into the interactions between institutional power and popular identification with the national polity. Popular nationalism and support for the authoritarian regime in China is often reduced to a result of top-down indoctrination and citizens are viewed as passive recipients of state-imposed propaganda. As William A. Callahan points out, Chinese nationalism is consumed in the reciprocal and interactive dynamics between official policy and popular feelings. ${ }^{37}$ On the one hand, the party state capitalises on ideas such as pride and injury that are deeply 'felt' by the public. On the other hand, 'individual' emotions towards the national community as an object of feeling are always embedded in shared myths, symbols, and meaning systems that are inseparable from institutional power. In the COVID-19 context, I will show that state actors employ a combination of censorship, direct persuasion, and hegemonic intervention as techniques of affective governance to suppress feelings that are considered dangerous, and mobilise those conducive to strengthening legitimacy and restoring continuity. While the strategy has been largely successful, especially when domestic debates are overshadowed by international geopolitics, unruly feelings remain visible in intermittent episodes of resistance and online commemorative practices.

\section{\#Grief: Trauma time and contested grievability in the COVID-19 crisis}

When the coronavirus outbreak first hit Wuhan in January 2020, the Chinese digital space saw unprecedented outcries of grief, anger, compassion, and desperation. We might say that these emotions became 'contagious' both through the circulation of the object of feeling - such as the spectacle of suffering and the evidence of governmental mishandling - and through the circulation of affect itself, which refers to a 'conscious or unconscious transmission of emotion within a social environment'. ${ }^{38}$ The severity of the new infectious disease was downplayed by public health authorities until 20 January, when its transmissibility between humans was finally announced. Only three days later, a strict cordon sanitaire was imposed in Wuhan, which would prohibit anyone from leaving the city for the following 76 days. Journalistic and first-person accounts of numerous human tragedies circulated on social media and devastated millions of spectators from afar. Netizens were able to follow heart-wrenching personal stories unfolding in real time, as numerous patients and family members took to Weibo to cry for help. They used the Internet to live tweet their helplessness, suffering, struggles, and loss. Some of these individual stories would later become remembered, narrativised, and symbolised as the human face of this catastrophic event beyond mere statistics. This section explores the contested politics of grief, mourning, and rage during the initial stage of the crisis. While public grieving over unbearable or unrecognised loss could lead to political anger, that is, potentially threatening to political legitimacy, the state took steps swiftly to suppress anger on the one hand and monopolise the ways life is grievable on the other.

The agonistic 'social drama ${ }^{39}$ the coronavirus crisis gave rise to is reminiscent of Edkins's concept of trauma time, or the time of the political as a moment that 'ruptures settled narratives and frames of meaning' and where 'a window for re-inscribing new understandings of the world emerges, albeit briefly. ${ }^{40}$ During the early days of the outbreak, traditional and new media actors engaged not only in documenting suffering and loss, but also in exposing various structural problems behind the public health and political crisis, such as the mismanagement of donated supplies, shortage of PPEs for frontline medical workers while officials were getting special

\footnotetext{
${ }^{37}$ William A. Callahan, China: The Pessoptimist Nation (Oxford, UK: Oxford University Press, 2010).

${ }^{38}$ Andrew A. G. Ross, Mixed Emotions: Beyond Fear and Hatred in International Conflict (Chicago, IL: University of Chicago Press, 2014), p. 21. However, Ross also points out that individuals may resist the transmitted affects or interpret them in different frameworks. Similarly, Ahmed suggests that 'it is the objects of emotion that circulate, rather than emotion as such.' Cultural Politics, p. 11.

${ }^{39}$ Liu, 'Social drama'.

${ }^{40}$ Duncan Bell, 'Introduction', in Bell (eds), Memory, pp. 1-29 (p. 10).
} 
supplies, and instances of rights violations in the implementation of lockdown measures throughout the country. ${ }^{41}$ Edkins further posits that trauma involves a betrayal, rather than simply being an encounter with 'brutality or death'. It takes place when 'the very powers that we are convinced will protect us and give us security become our tormentors' ${ }^{42}$ The following excerpt from one of the posts from a Wuhan resident, which was removed by Weibo soon after going viral, powerfully captures this sense of betrayal.

I know that not long from now ... we will hear unified cheering. People will be proud of the prosperity and strength of the nation. We will be constantly cheering the heroism and courage of today. But having seen the stories, I will refuse to join the celebration of the future....

We have been obedient since a young age - really obedient. ... We are willing to lock down our city, lock down our home, and remain silent.

We gave up all our rights in exchange for some protection.

But the day when the crisis hits us, I realize, with a broken heart, that there are no survivors under the dark sky. ${ }^{43}$

If the post above, along with numerous other critical comments that were widespread around that time, was censored because of its explicit questioning of settled narratives and reference to the fragility of existing orders, then the censoring of other online contents that display nothing but grief and loss may tell us more about the radical potential of mourning itself. This included a video that showed a daughter chasing after a van taking the body of her mother to a crematorium. The mother could not get tested before her passing and therefore could not be included in the official statistics. The public responses to this visual display of private grief demonstrated the capacity of images to invoke emotions and that, as Judith Butler puts it, 'grieving is bound up with outrage and outrage in the face of injustice or indeed of unbearable loss' is fundamentally political. Through the discursive practice of spectators, this image, in its specific sociopolitical context, was constituted as a symbol of not only unbearable personal loss, but also how the political authority had failed the individuals it was supposed to protect. The removal of the original post by Weibo after it triggered enormous, emotionally laden responses ironically attested to the subversive power it implicates.

Grieving and mourning (virtually) for lives lost in public may or may not be considered dangerous for sovereign power. In her influential reflection on grievability, Judith Butler argues that the globally differential distribution of grievability constitutes certain lives as grievable and (therefore) livable and others as not. ${ }^{44}$ What is central to the politics of grief and mourning in the COVID-19 crisis in China, however, is not only the question of when is life grievable, but also how is life grievable. David W. McIvor's distinction between the Periclean and Antigonean modes of public mourning offers a relevant analytical framework here. Whereas Periclean mourning is consensualist, functioning to reaffirm the status quo and 'depoliticize the past by seeing contingent victories through fantasies of inevitable progress', Antigonean mourning is agonistic, directing the grief over 'unrecognized loss' - or unrecognised

\footnotetext{
${ }^{41}$ Many of these reports were soon censored. A digital memory project archiving Chinese media coverage of the crisis is available at: \{https://drive.google.com/drive/folders/1tJzt1QrzBOZimg-HG_N7kaco6NnZ4a7-\}.

${ }^{42}$ Edkins, 'Remembering relationality', p. 109.

${ }^{43}$ Originally posted on 1 February 2020. An archived version of the text is available at China Digital Times: \{https://chinadigital-times.github.io/?/id/650171\}.

${ }^{44}$ Judith Butler, Frames of War: When is Life Grievable? (London, UK: Verso, 2009).
} 
accountability for the loss - towards 'struggles to challenge the status quo'. ${ }^{45}$ Trauma time, then, opens up a space for agonistic mourning to emerge, while state actors would move quickly to install linear narratives through, among others, practices of Periclean mourning rituals.

For the moral performance of the state to work, public grieving must be tolerated, or even encouraged when it takes the form of state-sanctioned collective rituals. But grieving in ways that demand recognition of structural failure or political responsibility can be fundamentally unsettling to the existing political order. This is when grief is tied up with rage, or political anger. This is an emotion that contains 'evaluative judgements' about what 'individuals' perceptions of the state have changed over the course' of a catastrophic event and how 'they understand their role in the political community. ${ }^{46}$ For Shirin Deylami, the politics of mourning and the politics of anger are intrinsically connected because 'we all feel grief and vulnerability (although these experiences are differential) but we also experience unfathomable anger at the conditions that produce that grief. ${ }^{47}$ From the perspective of the Chinese state, then, while grieving in certain ways is instrumental to disaster nationalism, the ways in which life is grievable must be managed, tamed, and devoid of anger.

The best example to illustrate the political nature of agonistic mourning and grief/rage is found at the night of Dr Li Wenliang's death on 7 February 2020. Dr Li alerted his colleagues to a SARS-like infectious disease in a private chat group on 30 December 2019. He was reprimanded by the Public Security Bureau for 'spreading rumours' and later diagnosed with COVID-19. The universal mourning for the young doctor on social media briefly turned into an explicit protest demanding freedom of speech before all relevant posts were removed by the platform. It also emerged that a Beijing-based data analytics company compiled a sentiment analysis report on public responses to Dr Li's death for the government. In this leaked report (Figure 1), the firm quantified the distribution of sentiments based on 'all web' data and offered policy recommendations on mitigating 'negative emotions' and 'especially the sentiment of anger'. ${ }^{48}$

What the authority needed to do, then, was to 'seize ownership of the pain' ${ }^{49}$ and monopolise the ways in which life is grievable. Major state media agencies published commentaries paying tribute to $\mathrm{Dr} \mathrm{Li}$ and, to varied degrees, reflecting on the importance of information transparency and other problems exposed by his mistreatment. On 5 March, Dr Li and 33 other medical professionals who passed away during the outbreak were awarded 'model individuals from the healthcare system in the prevention and control of COVID-19'. On 2 April, Dr Li and 14 other individuals were officially recognised as 'martyrs' (lieshi). By labelling him as a 'martyr' and appropriating dissensual public grief into consensualist mourning, the official narrative sought to transform the symbolic significance of $\mathrm{Li}$ as a 'whistleblower' who inspired protests and resistance into a traditional figure of a national hero who had sacrificed his life in the nation's collective fight against a ruthless disaster.

The national mourning day to commemorate the 'martyrs and lost compatriots in the battle against COVID-19' embodies the consolidation of Periclean mourning: rituals of group mourning that reaffirm collective identity, restore continuities, and bring about a closure. The editorial of People's Daily on the national mourning day provides a brief yet exemplary script of this. It states

\footnotetext{
${ }^{45}$ David W. McIvor, Mourning in America: Race and the Politics of Loss (Ithaca, NY: Cornell University Press, 2017), pp. 12, 40.

${ }^{46}$ Sonali Chakravarti, Sing the Rage: Listening to Anger after Mass Violence (Chicago, IL: University of Chicago Press, 2014), p. 21.

${ }^{47}$ Shirin Deylami, 'Burning rage', in Alexander Keller Hirsch and David W. McIvor (eds), The Democratic Arts of Mourning: Political Theory and Loss (Kindle edn, London, UK: Lexington Books, 2019).

${ }^{48}$ Gerry Shih, 'As anger explodes over doctor's death, Beijing firm gives Chinese government advice', Washington Post (8 February 2020), available at: \{https://www.washingtonpost.com/world/as-anger-explodes-over-doctors-death-beijing-firmgives-chinese-government-advice/2020/02/08/6899e3e6-4a52-11ea-9164-d3154ad8a5cd_story.html\}.

${ }^{49}$ Lisa Wedeen, Authoritarian Apprehensions: Ideology, Judgement, and Mourning in Syria (Chicago, IL: University of Chicago Press, 2019), p. 113.
} 


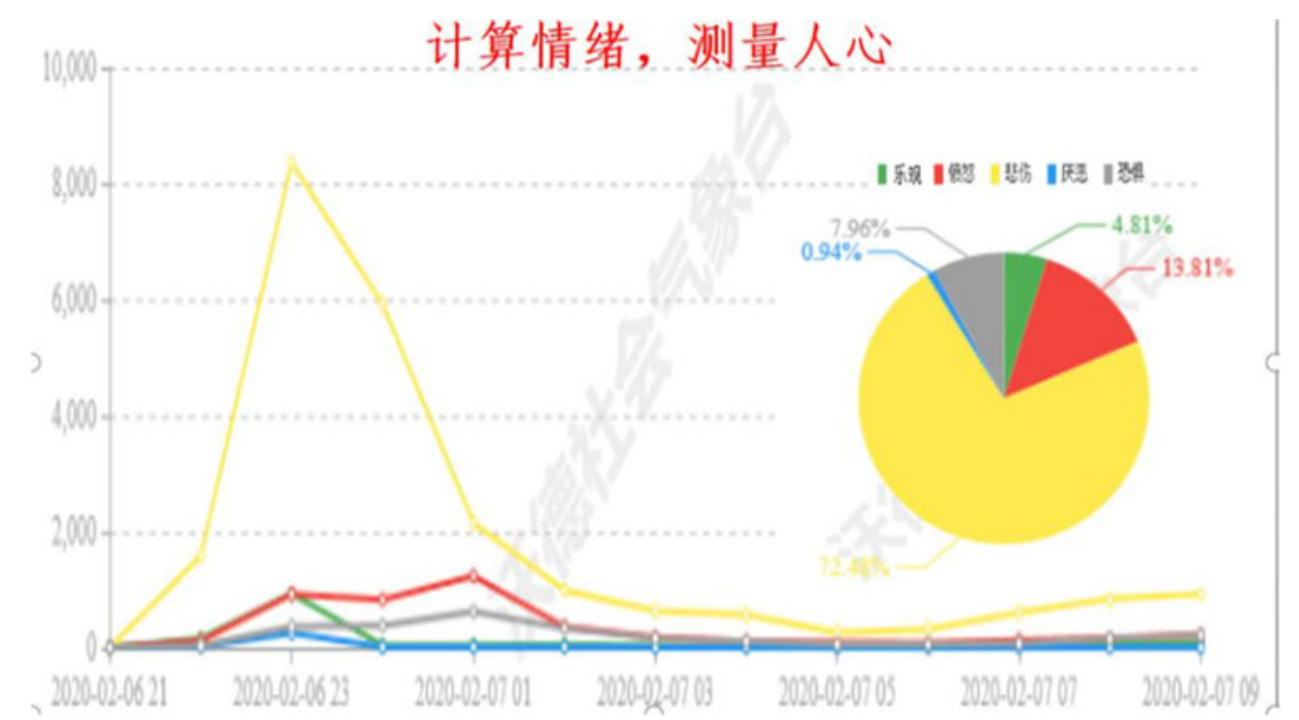

Figure 1. Sentiment analysis of 'total web data' within 24 hours before and after Dr Li Wenliang's death, from a report prepared by a private data analytics company for the government. The report was leaked to public domain on 7 February 2020. Titled 'Computing Emotion, Measuring the Heart', this chart quantifies the distribution of five sentiments: grief (yellow), anger (red), optimism (green), disgust (blue), and fear (green).

that the 'people's war' against the epidemic has shown that the party and the government always consider 'the people' and their lives in highest priority. It reiterates the historically oriented discourse that 'the Chinese nation has endured numerous disasters and yet she has never been defeated but always grown stronger from the hardship'. Finally, the editorial concludes with the following:

May the deceased rest in peace and may the living be strong. Carry forward the great national spirit, overcome all difficulties and challenges, and move from victories to new victories. This is the best way to commemorate the deceased and the incumbent duty of the living. ${ }^{50}$

While the message from state media typifies conservative mourning, which is about moving beyond the past without reckoning with the past or instituting any political changes, popular narratives of mourning and remembrance appear more diverse and ambiguous. As the objects of emotion circulate, members of the audience may situate them within different interpretive paradigms in their affective-discursive practices. I would like to illustrate this by juxtaposing two viral posts from the national mourning day, one of which was censored, and the other was not. Both posts recalled the same symbolic stories of individual suffering that had come to define the public memory of the catastrophic event: such as the aforementioned daughter chasing the van carrying her deceased mother to the crematorium, a boy with cerebral palsy who died after his father was taken into quarantine, and a retired elderly man who learned to use the Internet to seek for help and later died from COVID-19.

The censored post, which garnered at least 157,262 likes before being removed, recounted more 'political sensitive' stories such as that of a citizen journalist who was detained for reporting independently from Wuhan. It also mentioned the misfortune non-COVID patients faced

\footnotetext{
50缅怀逝者, 勇毅前行 [Commemorating the deceased, moving forward with courage and determination]', People's Daily (4 April 2020), available at: \{https://weibo.com/ttarticle/p/show?id=2309404490060954206480\}.
} 
because of the travel ban and grievances caused by arbitrary implementation of draconian lockdown policies. The post did not make any comments beyond simply retelling these symbolic personal stories. ${ }^{51}$ The uncensored post, which has received over 560 thousand retweets and over 1.2 million likes, made the following reflection after recounting the stories:

It is only because our nation always remembers the past that she has survived 5,000 years of bumpy road, even though for several times the nation was almost destroyed and the race annihilated (wangguo miezhong).

This Qingming Festival, the whole nation mourns. The Chinese nation will live long and prosper. $^{52}$

Other users also engaged in this virtual memorialisation by mentioning the tragedies they had remembered from the outbreak in the over 50,000 comments this post has attracted. There was an outpour of grief, sadness, and compassion in the recounting of these heart-wrenching tragedies. However, as Rebecca Adler-Nissen, Katrine Emilie Andersen, and Lene Hansen have noted, a 'range of diverse emotions might be brought together in discourse' to constitute the meaning of emotionally charged images or personal stories and locate political responsibility in different ways. $^{53}$ In this case, one could acknowledge the pains and dignity of individual human beings and assert that they 'must not be forgotten', while at the same time embedding their emotional responses within the hegemonic framework of interpretation. This is one that depoliticises this particular disaster and subsumes it under an imagined continuous history of the national community rising above recurrent challenges. The censorship machine certainly amplifies this hegemonic narrative by silencing alternative ones, yet as I have argued earlier, popular identification with officially endorsed imaginations about the nation should not be reduced to a mere product of top-down indoctrination. On the other hand, one could also articulate a more radical emotional bundling that links grief to political anger and a demand, even if implicitly, to redress injustices and recognise political responsibility. In the latter case, the grieving for lives lost and the memorialisation of personal sufferings articulates an alternative notion of the political community: a community of shared vulnerability to the rule of a political system that is not only complicit in producing the violence they have witnessed, but also works in full force to silence critical reflections.

\section{\#Gandong: Moving the public with a digital recasting of heroism, national unity, and positive energy}

Gandong refers to the emotional state of being moved or touched in a way that often leaves one inspired to effect positive change. ${ }^{54}$ The most prominent example of its political use in China's

\footnotetext{
${ }^{51}$ An archived version of the post is available at: $\{$ https://chinadigitaltimes.net/chinese/640712.html\}. The blogger was later sentenced to six months on charge of 'picking quarrels and provoking trouble’. ‘散布涉新冠疫情虚假信息, 微博网民“玛 丽莲梦六”获刑6个月 [Weibo user is sentenced to 6 months for spreading rumour]', The Paper (23 February 2021), available at: $\{$ https://www.sohu.com/a/452104829_260616\}.

${ }^{52}$ Guantouchen (4 April 2020), available at: $\{$ https://weibo.com/1786937891/IBFGs9I3J\}.

${ }^{53}$ Adler-Nissen, Andersen, and Hansen, 'Images', p. 94.

${ }^{54}$ Psychologists have recently studied similar experiences across different cultures and referred to the emotional state as kama muta, which is commonly associated with sensations of 'warmth in the chest' and tearing up. While individuals experience kama muta in vastly different contexts (whether being moved by a love story or by the bravery of soldiers), they note that it evokes 'adaptive motives to devote and commit to' communal sharing relationships. Alan Page Fiske, Beate Seibt, and Thomas Schubert, 'The sudden devotion emotion: Kama Muta and the cultural practices whose function is to evoke it', Emotion Review: Journal of the International Society for Research on Emotion, 11:1 (2019), pp. 74-86; Alan Page Fiske, Kama Muta: Discovering the Connecting Emotion (London, UK: Routledge, 2019). Takaji's investigation of kandoh, the Japanese equivalent to gandong, shows that it typically involves both joy and sadness. Akihiko Tokaji, 'Research for
} 
affective governance is an annual show of CCTV named 'Moving China (gandong zhongguo): Persons of the Year', which has been running since 2002. ${ }^{55}$ The show selects and honours ten figures each year whose deeds potentially 'move' the nation and the public into tears. Their personal stories typically involve suffering and hardship, but the propagation of these stories aims to elicit a feeling of gandong among the public who are expected to become inspired, more morally committed, and more patriotic. ${ }^{56}$ In this section, I explore how familiar themes of heroism and national unity in disaster nationalism are adapted to the digital culture of participation and connectivity with a particular focus on gandong: one is (encouraged to be) moved, in a positive manner, by the bravery of the heroes, the unity of the people, and the strength and resilience of the nation facing unprecedented challenges. The emotional state of being moved is both an object of affective governance and a spontaneous response of internet users as compassionate citizens. However, the ambivalence of emotional politics and the fact that the propaganda apparatus' efforts to induce gandong often relies on a display of suffering means that there is always a potential for them to bring forth counterhegemonic narratives.

As mentioned earlier, the official mourning for Dr Li Wenliang framed him as a 'martyr' who had sacrificed his life in the nation's fight against a war-like epidemic, and the national mourning day was set up to commemorate first of all the 'martyrs' who had lost their lives in the 'war' against the virus, and secondly the victims. The emphasis on martyrdom in nationalist tropes exemplifies attempts to bind the 'negative' emotion of grief with the 'positive' feeling of being moved and inspired. The discourse of heroism (if not martyrdom) is widely observed during the pandemic crisis across the world, often in combination with the deployment of war metaphors. ${ }^{57}$ Militarised languages frame disasters as the 'enemy' of not only individual human lives, but also of the nation, which justify emergency measures and calls upon all members of the national community to unite behind the political leadership. In their analysis of Chinese state media reports on disasters since the 1950s, Yan Yan and Guanyu Wang show how the honouring of 'saviours' and the construction of the 'saviour-survivor' community mobilises the masses' political and cultural identification with the 'family-state'. ${ }^{58}$ Peter C. Pugsley argues that hero-making in times of crisis serves as a means of distraction and depoliticises a disaster by creating 'a solvable situation' that would showcase the 'might and power of the people'. ${ }^{59}$ Telling 'moving' stories of heroism thus is instrumental to regime legitimation by cultivating nationalist sentiments and distracting attention from scrutinising structural causes of the disaster and responsibilities of governmental actors.

In the COVID-19 outbreak, medical workers were referred to as 'white-clothed soldiers' (baiyi zhanshi) in the battle against the epidemic (zhanyi). Some 40,000 medical workers dispatched

determinant factors and features of emotional responses of "kandoh" (the state of being emotionally moved)', The Japanese Psychological Research, 45:4 (2003), pp. 235-49.

${ }^{55}$ CCTV (China Central Television) is a predominant state-owned broadcaster.

${ }^{56}$ Among the ten awardees of Moving China 2020 were Zhang Dingyu, the president of Jinyintan hospital who fought on the COVID-19 frontline despite suffering from amyotrophic lateral sclerosis, and He Yong, a delivery worker in Wuhan who drove healthcare workers to work for free. For a critique of the 'gandong model' in disaster reporting in Chinese-language scholarship, see Yueqin Huang, “心灵鸡汤”与灾难叙事的情感规驯 - 传媒的社交网络实践批判 [“Chicken soup for the soul” and emotional disciplining in disaster narratives]', Wuhan University Journal of Humanity and Social Science, 69:5 (2016), pp. 114-18.

${ }^{57}$ Costanza Musu, 'War metaphors used for COVID-19 are compelling but also dangerous', The Conversation (8 April 2020), available at: \{https://theconversation.com/war-metaphors-used-for-covid-19-are-compelling-but-also-dangerous$135406\}$.

${ }^{58}$ Yan Yan and Guanyu Wang, “共同体的凝聚、分化和退场: 建国以来官方救灾话语的共现结构之演变 [The condensation, division and disappearance of the savior-survivor community: The evolution of the co-occurrent structure of the official disaster discourse in China]', Journalism and Communication Studies, 10 (2018), pp. 97-128. The Chinese concept of jiaguo or family-state envisions the nation-state as an analogous extension of the family.

${ }^{59}$ Peter C. Pugsley, 'Constructing the hero: Nationalistic news narratives in contemporary China', Westminster Papers in Communication and Culture, 3:1 (2006), pp. 78-93 (p. 87). 
from other provinces to help manage the outbreak in Hubei became an epitome of heroic sacrifice and national unity. Both their departures and returns were highly publicised by state media through affective communications on social media. For example, People's Daily published a series of posts on Chinese New Year's Eve depicting the scenes of medical workers saying goodbye to their families before leaving for Hubei. One of them read: 'this is \#the most moving hug on New Year's Eve\#. On the night for family reunion ... \#Doctors from across the country are rushing to help Hubei\#. Hope you return home safely!' The text was accompanied by a video showing dispatched medical workers hug their families in tears. ${ }^{60}$ If the visual representation of the departure scenes intended to move the public by highlighting self-sacrifice and devotion, then the social media campaigns publicising their returns two months later - through high-profile ceremonies staged in both Hubei and their home provinces - were focused on conveying gratitude, victory, and the strength of the nation. Chinese flags were ubiquitous in these ceremonies where local people of Hubei sent off medical workers with gratitude and tear or home provinces welcomed the return of national heroes with pride. Citizen spectators were not only able to watch these emotional scenes closely on social media, but also encouraged to participate in the discussion and express their own heart-felt gratitude. A hashtag initiated by CCTV News - \#thank you for risking your life for Hubei\# - in March 2020 has received 4.54 billion reads and 19.19 million discussion threads at the time of writing.

As every individual citizen is expected to observe certain rules and play their part in bringing the pandemic under control, state media accounts also dedicated a series of campaigns to recognising the contribution of essential workers across different sectors and ordinary citizens in general. People's Daily initiated the hashtag \#thank you, every ordinary Chinese\#, which has attracted 590 million reads and 124,000 discussion threads. Through a series of images posted from February to April 2020 (Figure 2), the campaign paid tribute to groups such as volunteers, PPE factory workers, community workers, delivery workers, as well as the ' 1.4 billion Chinese people'. The celebration of ordinary heroism is not entirely new, though the figure of the hero was typically reserved for soldiers and self-sacrificial role models before the 2008 earthquake. The representations of the earthquake, however, accentuated a new motif in official disaster discourse that is honouring citizen volunteers and co-opting spontaneous humanitarian civicmindedness as a mandate' of the state itself. ${ }^{61}$ COVID-19 narratives have continued to develop this affective technology that calls for gratitude to not only the party leadership and medical workers, but also 'every ordinary Chinese', which creates a 'dialectical unity' between 'the people' and the party state. ${ }^{62}$ It is worth mentioning that in one of the posters, People's Daily dedicated special thanks to the residents of Wenchuan, the epicentre of the 2008 earthquake. The image showed a Wenchuan villager driving a lorry to deliver fresh vegetables to Wuhan, with the slogan 'Wenchuan is grateful. Wuhan must rise' written on a red banner. The reference to the earthquake constructs intertextual links with previous national tragedies and reinscribes established disaster narratives centred around gratitude, continuity, and unity.

Indeed, gratitude (gan'en) is another central concept in the Chinese regime of affective governance that cannot be dealt with properly within the limited scope of this article. Gratitude as a legitimating affective disposition has been actively promoted by the party state and demanded from, most evidently, ethnic minorities and disaster victims, in their disciplining as grateful and indebted subjects. ${ }^{63}$ One might distinguish citizens' spontaneous expression of

\footnotetext{
${ }^{60}$ As there is no space between Chinese words, Weibo adopts a double-hash format to create hashtags, also known as topics (huati). People's Daily (25 January 2020), available at: $\{$ https://weibo.com/2803301701/Ir2bWCuvA\}.

${ }^{61}$ Jennifer Hubbert, 'The biopolitics of gratitude and equivalence: Debt, exchange, and disaster politics at the Shanghai World's Fair', Verge: Studies in Global Asias, 3:1 (2017), pp. 162-88.

${ }^{62}$ Kailing Xie and Yunyun Zhou, 'The cultural politics of national tragedies and personal sacrifice', Made in China, 6:1 (2021), pp. 24-9.

${ }^{63}$ Christian Sorace, 'The Chinese Communist Party's nervous system: Affective governance from Mao to Xi', The China Quarterly, pp. 1-23; Qiaoyun Zhang and Yang Zhan, "Gratitude education”: Aid-as-gift and the agency of recognition in
} 

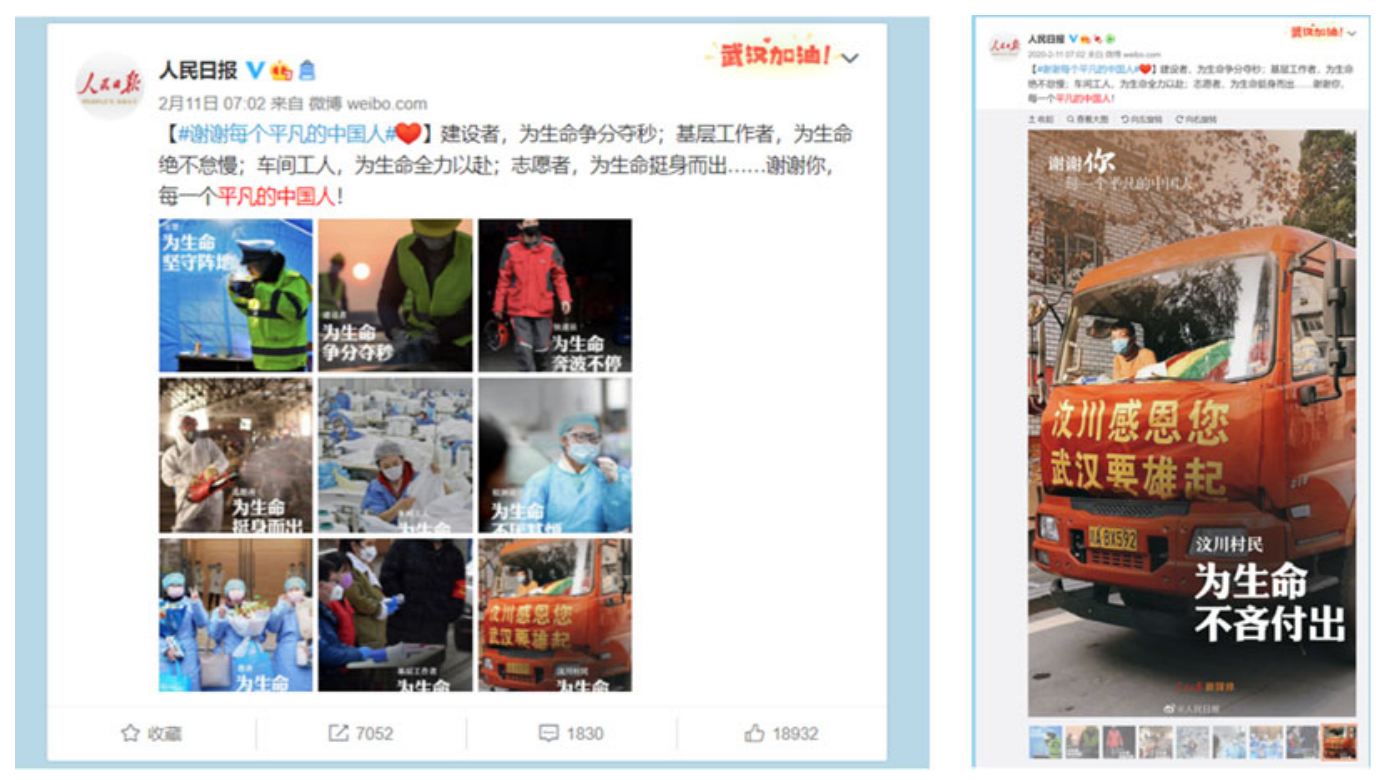

Figure 2. Left: one of a series of posts from People's Daily's Weibo campaign 'Thank You, Every Ordinary Chinese'. Right: an image from the post paying special tribute to the residents of Wenchuan. Screenshots taken by the author on 2 September 2020 .

appreciation for essential workers, which is a ubiquitous scene across the world during the pandemic, from the ruling authorities' orchestration of gratitude to not only the workers but also political leadership. However, public displays of gratitude could be appropriated by politicians to distract attention from systematic failures and responsibilities in both democratic and nondemocratic settings, as for example suggested by critical reflections on the 'clap for our carers' campaign. ${ }^{64}$ Meanwhile, the politics of gratitude in the wake of COVID-19 in China has not gone uncontested despite the constraints of authoritarian rule. A local party official's call for Wuhan residents to be grateful was met with criticisms and resistance. As Christian Sorace posits, the refusal of gratitude was 'an ethical and aesthetic gesture' that 'makes a temporary cut in ideology'. ${ }^{65}$ A widely circulated poem written by a nurse working in one of the makeshift hospitals in Wuhan contains the following lines: 'The slogans are yours / The praises are yours / The propaganda, the model workers, all yours ... Please, don't decorate me in garlands / Don't give me applause ... I invite you to go look, if you are able / At those washed out homes / Does smoke rise from the chimneys / The cell phones drifting about the crematorium / Have their owners been found?' 66 Rejecting the 'feel-good politics' of gratitude and gandong, the poem recentres the disaster narrative around the recognition and remembrance of the losses that are still to be reckoned with.

Chinese ethnic governance', Journal of Contemporary China, 30:132 (2021), pp. 960-76; Hubbert, 'The biopolitics of gratitude'.

${ }^{64}$ See, for example, Owen Jones, 'While the UK's key workers lack PPE, ministers clapping for them is an insult', The Guardian (24 April 2020), available at: \{https://www.theguardian.com/commentisfree/2020/apr/23/uk-key-workers-ppe-ministers-clapping-protect-nhs\}. Sorace discusses gratitude as the 'ideology of sovereignty in crisis' in both China and the US. Christian Sorace, 'Gratitude: The ideology of sovereignty in crisis', Made in China Journal, 5:2 (2020), pp. 166-9.

${ }^{65}$ Sorace, 'The Chinese Communist Party's nervous system', p. 18.

${ }^{66}$ This translation is by China Digital Times (21 February 2021), available at: $\{$ https://chinadigitaltimes.net/2020/02/translation-poems-from-a-wuhan-nurse/\}. 
While these have been recurrent themes in Chinese disaster discourse, the technological affordances of social media platforms have enabled state media to develop a variety of techniques to popularise and 'humanise' political communications, including promoting influencers who benefit commercially from producing nationalistic content, co-opting grassroots youth culture, and encouraging internet users to be 'thought work collaborators' through social media engagement. ${ }^{67}$ The coronavirus outbreak gave rise to an outpouring of civic engagement and in China's booming digital culture, numerous images, videos, and songs invoking solidarity and patriotism were created by both state-affiliated and private actors and circulated among an audience in the millions. One of the techniques state media accounts employ within the 'networks of socio-technological engagement ${ }^{\text {'68 }}$ is curating and reposting visual contents produced by private internet users, which commonly capture moments of courage, humour, and mutual aid amid unprecedented challenges of the pandemic. Official appropriations of these digital practices can be oriented towards generating an ambience of 'positive energy' rather than explicitly political messaging. The 'rawness' and apparent spontaneity of user-generated contents render the storytelling less superficial and propagandist, more authentic, experiential, and easier for the audience to sympathise with. State media accounts reposted videos documenting everyday life such as the vlogs made by medical workers and patients in Wuhan's makeshift hospitals and a surprise welcome home celebration a dispatched medical worker received from her colleagues upon her return from Hubei. ${ }^{69}$ An iconic image both CCTV and People's Daily shared on 5 March 2020 showed a young doctor (dispatched from Shanghai) and an elderly patient, in his hospital bed, stopping for a moment to enjoy the sunset together (Figure 3). The image, taken casually by a student volunteer with his mobile phone, reached thousands of likes and reposts in Chinese cyberspace and beyond. Dubbed 'the sunset picture that moved China', it was later acquired by the National Museum. These posts did not contain overt ideological persuasion, but instead highlighted how 'touching' and 'heart-warming' these mundane moments are, frequently featuring the 'red heart' and 'loudly crying face' emojis. Netizens responded overwhelmingly with comments revealing how 'moved' they were, and some also expressed patriotic sentiments through phrases like 'Go China!' or 'Believe in us, believe in China!'.

To make sense of the affective politics of gandong, it should be noted again that popular nationalism emerges and operates at the interface between the ideological work of the state and the desires, hopes, and fears of the citizens. 'Positive energy' as a hegemonic affective atmosphere provides a particularly suitable proxy for the convergence between embodied personal feelings and the persuasive power of the state. An interview-based research finds that a majority of the participants exhibited a preference for 'positive energy' content in their consumption of COVID-19 information on Chinese social media, partly to overcome fear and anxiety. ${ }^{71}$ One should not assume that every user who shared or was moved by the 'heart-warming' stories promoted by the propaganda apparatus is 'emotionally manipulated', or that their being moved

\footnotetext{
${ }^{67}$ Maria Repnikova and Kecheng Fang, 'Authoritarian Participatory Persuasion 2.0: Netizens as thought work collaborators in China', Journal of Contemporary China, 27:113 (2018), pp. 763-79; Zou, 'Restyling propaganda'.

${ }^{68}$ Florian Schneider, 'China's viral villages: Digital nationalism and the COVID-19 crisis on online video-sharing platform Bilibili', Communication and the Public (2021), available at: \{DOI: 10.1177/2057047321104802\}. Schneider's analysis of a video sharing platform shows how algorithmically enabled dynamics of sociotechnical engagement generates 'recursive feedback loops of community sentiments', p. 15.

${ }^{69}$ For a case study of the circulation of vlogs made in makeshift hospitals, see Ralph Litzinger and Yanping Ni, 'Inside the Wuhan cabin hospital: Contending narratives during the COVID-19 pandemic', China Information (2021), available at: \{DOI: $10.1177 / 2$ F0920203X211030869\}.

${ }^{70}$ Comment thread of a Weibo post from CCTV sharing a personal diary of a COVID-19 patient, available at: \{https:// weibo.com/2656274875/IvrgQDlAo\}.

${ }^{71}$ Zhicong Lu et al., "Positive energy": Perceptions and attitudes towards COVID-19 information on social media in China', Proceedings of the ACM on Human-Computer Interaction, 5:CSCW1 (2021).
} 


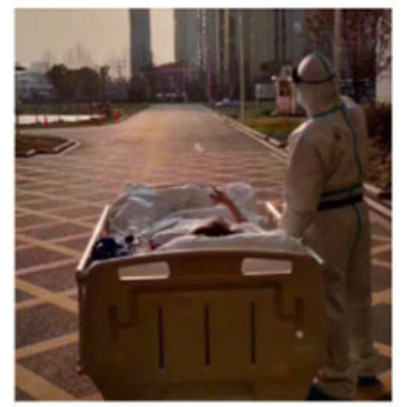

落日余略下这个略间

刻做心

Figure 3. CCTV's Weibo post sharing the iconic sunset watching image: '\#Doctor stops for patient to enjoy the sunset\# This moment under the sunset is forever unforgettable [crying face emoji] Share! Save! At the east division of Wuhan University People's Hospital, Dr Liu Kai from Shanghai stops on his way to accompany a patient to a CT scan, so that the 87-year-old patient who has been hospitalised for almost a month can enjoy the sunset ... the two figures under the sunset are so heart-warming [red heart emoji]'. Screenshot taken by the author on 10 June 2021.

necessarily indicates identification with official ideology. What is key here is that state media's purposeful curating of user-generated content about everyday heroism and 'movingness' offers an opportunity for social media users to align private feelings with the officially sanctioned interpretative paradigm, while the possibilities for being moved in alternative ways remain open. ${ }^{72}$

Just like the demand for gratitude, the mobilisation of gandong can also backfire, especially during the early phase of the crisis, as it often relies on a display of suffering and (excessive) sacrifice to move the audience into tears. On 10 February 2020, People's Daily propagated a story about a 87-year-old woman who donated her lifetime saving to help fight the outbreak in Wuhan, ${ }^{73}$ with the emoji of loudly crying face employed in the post. While the story was supposed to 'move' the public, it was flooded with criticisms and \#do not propagate elderly people's donation\# became a trending hashtag on Weibo. Another case in point is the feminist condemnation of the overemphasis on female sacrifice in official propaganda. While the majority of the 'heroes' and 'saviours' in this 'battle' against the virus were women health workers, the praising of their contribution in state media remains within the framework of patriarchal authoritarianism. Reports praised how nurses continued to 'fight on the frontline' when they were nine months

\footnotetext{
${ }^{72}$ As Ngai reminds us, 'The fact that feelings of being moved have become vulnerable to being displaced by or even conjoined to feelings of manipulation does not mean that there is no longer powerful aesthetic feeling.' Sianne Ngai, Our Aesthetic Categories: Zany, Cute, Interesting (Cambridge, MA: Harvard University Press, 2012), p. 27.

${ }^{73}$ People's Daily (10 February 2020), available at: $\{$ https://weibo.com/2803301701/ItzTyl8ds $\}$.
} 
pregnant and how female medical workers volunteered to shave their head to go to Hubei, accompanied with photographs showing them in tears while being shaved. The instrumentalisation and staged humiliation of the female body in these narratives prompted widespread criticisms among Chinese feminists who have maintained a growing presence online. ${ }^{74}$ These examples illustrate the inherent uncertainties in deploying governmental techniques that work on and through the emotional, as the coherence between the 'encoding of affect' by the content producer and the 'inscriptions of affective reactions in the comments' are never guaranteed. ${ }^{75}$ While affective governance seeks to elicit a positive feeling of gandong from the (visual) representation of heroism, individual sacrifice, and communal solidarity, responses to and interpretations of such representation remain fundamentally unstable.

\section{\#Enmity: Pandemic geopolitics and the co-construction of rivalries}

As we have shown, the official and popular narratives of COVID-19 on social media during the crisis in the early months of 2020 builds on and adapts the pre-existent disaster nationalist discourse. This typically revolves around emphasising national cohesion and strengthening national identity through the celebration of heroism and rituals of consensualist memorialisation. However, as the outbreak became contained domestically and the virus spread across the world, COVID-19 narratives in China became both shaped by and constitutive of the geopoliticisation of the pandemic at the international level. The apparent success with epidemic control in China and the mishandling of the pandemic in certain Western countries, which are China's geopolitical and ideological other in a dichotomous framework co-produced by both sides of the divide, provides a convenient context for the victorious narrative to prevail and critical voices to be marginalised. Furthermore, the recognition of increased external hostility helps engender a 'rally-round-the-flag' effect, ${ }^{76}$ which not only reacts to and constitutes the contemporary rivalry politics, but also builds on and invokes historical memories of injury.

In terms of affective intensities, online narratives during the normalisation phase appear less emotionally charged than those during the height of the outbreak. However, enmity, resentment, and contempt are discernible in popular imaginaries of international rivalries and, in particular, the 'politics of blaming' between China and the United States (US). ${ }^{77}$ To be sure, 'negative' feelings are not the only ones at play in the discursive production of pandemic geopolitics. Friendship and gratitude are also emphasised in both official and popular narratives, as we could see from, for instance, the sentimentalist coverage of the Serbian president's 'gratitude' for Chinese assistance. ${ }^{78}$ Constrained by space, however, the discussion here is limited to examining the discursive construction of binary oppositions between China and the West, especially the US, along two intrinsically interlocking parameters: geopolitical (power politics) and ideological (regime superiority).

The perception of and responses to geopolitical struggles became integral to Chinese narratives of COVID-19 as the pandemic developed into a global crisis, which triggered blame, scapegoating, and racialised Sinophobic sentiments in international society, especially from the US as

\footnotetext{
${ }^{74}$ For more on feminist online activism during COVID-19, see Shirley Xue Yang and Bowen Zhang, 'Gendering Jiang Shanjiao: Chinese feminist resistance on Weibo during the COVID-19 lockdown', International Feminist Journal of Politics, 23:4 (2021), pp. 650-5; Yue Yang, 'When positive energy meets satirical feminist backfire: Hashtag activism during the COVID-19 outbreak in China', Global Media and China (2021), available at: \{DOI: 10.1177/2F20594364211021316\}.

${ }^{75}$ Britta T. Knudsen and Carsten Stage, 'Online war memorials: YouTube as a democratic space of commemoration exemplified through video tributes to fallen Danish soldiers', Memory Studies, 6:4 (2013), pp. 418-36 (p. 420).

${ }^{76}$ Xiangfeng Yang, 'Domestic contestation, international backlash, and authoritarian resilience: How did the Chinese party-state weather the COVID-19 crisis?', Journal of Contemporary China, 30:132 (2021), pp. 915-29.

${ }^{77}$ Bernadette Nadya Jaworsky and Runya Qiaoan, 'The politics of blaming: The narrative battle between China and the US over COVID-19', Journal of Chinese Political Science, 26:2 (2021), pp. 295-315.

${ }^{78}$ See, for example, the hashtag \#Serbian president thanks China three times at press conference\#.
} 
China's 'most significant other' ${ }^{79}$ Even before the epidemic became a global crisis, this dynamic was already exemplified in the controversy involving a Washington Post article titled 'China is the Real Sic Man of Asia', published on 3 February 2020. The article was perceived and framed as a typical case of ruhua (humiliating China) among the Chinese public, as the metaphor of the 'sick man of Asia' is profoundly associated with collective memories of national trauma and humiliation resulted from Western imperialism. In protest at the article, the Chinese government revoked the press credentials of three reporters from the outlet and effectively expelled them from the country. While People's Daily's Weibo post on this event only cited the official press release, which employed a relatively neutral, bureaucratic language, top comments in the thread displayed a mix of anger, despise, and taking pride in the government's 'strong' stance against 'smearing' and 'bullying' ${ }^{80}$

This early episode from the 'narrative war' around the pandemic between the US and China shows that on the Chinese side, reactions to the accusatory dynamic draw in particular on the resource of victimhood nationalism, which is engendered through sustained 'narrations of perceived or real collective trauma' ${ }^{81}$ The constant reproduction of victimhood has been a salient emotional source of Chinese popular nationalism, which is increasingly coupled with the recognition that the nation is now a great power worthy of respect and will no longer 'tolerate bullying from the imperialist West' ${ }^{82}$ Any criticisms from the West, therefore, tend to be dismissed as biased, unjust, and geopolitically motivated to undermine a rising China. Throughout the pandemic, invocations of victimhood and senses of being wrongly targeted and maliciously smeared by the hegemonic West, especially the US, have been a prominent theme in popular and official narratives of COVID-19. In her analysis of online discussions of Western responses to the pandemic, Xiaoyu Zhao highlights some of the emotionally stirring catchphrases that portray a hostile international environment determined to contain or even destroy China, such as 'the imperialists' ambition to destroy us never dies' and 'they do not care about if you are innocent; they only want you to commit suicide. ${ }^{83}$ While the official discourse is generally more constrained, the appeal to victimhood and historical trauma has been unequivocal. In May 2020, Hua Chunying, spokesperson of the Ministry of Foreign Affairs (MFA), juxtaposed Washington's blame of China for the pandemic with the Paris Peace Conference in 1919, an event that symbolises national humiliation in collective memory, and asserted that ' 1.4 billion Chinese people will never concede to bullying. ${ }^{, 84}$ Echoing her message and invoking a phrase routinely used to characterise that historical period, 'the loss of rights and the humiliation of the nation' (sangquan ruguo), People's Daily declared in its Weibo post that 'the days when the Chinese nation suffered from endless bullying are forever gone!' By drawing analogies between China's traumatic encounters with Western imperialism a century ago and the international hostility the nation is faced with in the current conjuncture, such rhetoric capitalises on and regenerates popularly rooted victimhood identity to mobilise nationalist sentiments against the perceived external enemy. Furthermore, as the narrative war between China and the US surrounding the pandemic escalated, conspiracy theories and disinformation about the

\footnotetext{
${ }^{79}$ Michael Alan Brittingham, 'The "role" of nationalism in Chinese foreign policy: A reactive model of nationalism \& conflict', Journal of Chinese Political Science, 12:2 (2007), pp. 147-66.

${ }^{80}$ Weibo shows most 'liked' comments at the top of a comment thread. Some of the top comments include: 'Well done!'; 'They must apologize!'; 'Get out of China! The 1.4 billion people of China do not welcome those who smear us in bad faith'; 'Do not think China can be easily bullied'. Available at: \{https://weibo.com/2803301701/IuVI5myVR\}.

${ }^{81}$ Adam B. Lerner, 'The uses and abuses of victimhood nationalism in international politics', European Journal of International Relations, 26:1 (2020), pp. 62-87.

${ }^{82}$ Jaworsky and Qiaoan, 'The politics of blaming'.

${ }^{83}$ Xiaoyu Zhao, 'A discourse analysis of quotidian expressions of nationalism during the COVID-19 pandemic in Chinese cyberspace', Journal of Chinese Political Science, 26:2 (2021), pp. 277-93. The first phrase is attributed to Mao during the Cold War and has regained popularity recently on social media. The second phrase is a reference from the film Let the Bullets Fly (2010).

${ }^{84}$ People's Daily (6 May 2020), available at: $\{$ https://weibo.com/2803301701/J0GmC0xNA\}.
} 
virus origin spread on both sides of the divide, which fed on 'a surging economy of emotions' in a spiral of retaliatory moves. ${ }^{85}$

When the feelings of enmity, antagonism, and suspicion are directed against perceived foreign adversaries, they are no longer seen by authorities as negative emotions requiring mitigation or suppression, unlike in the context of maintaining domestic political stability. As Sara Ahmed notes, turning the nation into an object of love involves the 'organization of hate' for others and a defence against 'our injury'. ${ }^{86}$ If enmity and antagonism characterise the affective dimension of narratives about pandemic politics as great power competitions, then those on the superiority of the Chinese regime vis-à-vis 'Western liberal democracies' are more permeated by contempt and indifference towards the other and pride in the national self. To be sure, the assertation that the Chinese regime is more capable than liberal democracy in dealing with disasters and puts more emphasis on 'placing lives above anything else' is not new in the official disaster discourse. $^{87}$ However, the global development of the pandemic has particularly boosted the attractiveness of this dichotomous framing of ideological competition. This also needs to be understood within the larger shift in online discourse from a largely 'legitimacy-challenging imaginary grounded in (Western) democratic reference' towards a more regime-supportive framework of 'civilizational competition' in the past decade. ${ }^{88}$ There has been a growing consensus on the grassroots level that China's rise is attributed to the advantages of the Chinese political system and the various crises facing Western democracies reveal the pitfalls of liberal democratic values, which used to be appealing to educated urbanites in China who now claim to have become disillusioned. ${ }^{89}$

Against the backdrop of pre-existing tensions and the discursive shift in digital space, discussions of epidemic responses in Western countries accentuate and ridicule questionable aspects such as the idea of 'herd immunity' and the resistance to mask wearing, conveniently operating within a binary framework of a competent, science-based 'China model' that prioritises human life versus the incompetent and unscientific 'Western approach' that privileges freedom over life. ${ }^{90}$ Internet memes such as '[other countries should] copy China's homework' became so popular that even the MFA referred to the phrase to reject the accusation that China was exporting its model of governance through medical assistance. As with previous disasters, the official narrative has continued to underscore how the fight against the pandemic represented the value of 'placing people above anything else, placing human life above anything else' unique to the Chinese regime. ${ }^{91}$ Schneider and Hwang note that in the context of the Sichuan earthquake, the emphasis on human life resonates with the official discourse on human rights that prioritises the right to subsistence and development over political freedoms, ${ }^{92}$ and that implicitly places one in opposition to the other. In the case of COVID-19, social media users actively participate in quotidian discursive practices that contrast the allegedly 'real' human rights of China with the

\footnotetext{
${ }^{85}$ Sheng Zou, 'Mistranslation as disinformation: COVID-19, global imaginaries, and self-serving cosmopolitanism', Cultural Studies, 35:2-3 (2021), pp. 523-33 (p. 529). Disinformation campaigns implying the US origin of the virus on Chinese social media involved both the manoeuvring of state media and the participation of ordinary users, who may attract traffic and benefit financially in the digital attention economy by producing contents that tap into popular nationalist sentiment.

${ }^{86}$ Ahmed, The Cultural Politics.

${ }^{87}$ Schneider and Hwang, 'The Sichuan earthquake'.

${ }^{88}$ Angela Xiao $\mathrm{Wu}$, 'The evolution of regime imaginaries on the Chinese Internet', Journal of Political Ideologies, 25:2 (2020), pp. 139-61.

${ }^{89}$ Chenchen Zhang, 'Right-wing populism with Chinese characteristics? Identity, otherness and global imaginaries in debating world politics online', European Journal of International Relations, 26:1 (2020), pp. 88-115.

90، 口罩里的东西方之争：生命至上还是自由至上? [The West versus the East in mask wearing: Life first or freedom first?]', The Paper (16 November 2020), available at: \{https://www.sohu.com/a/432138087_260616\}.

${ }^{91}$ This phrase, 'renmin zhishang shengming zhishang', also topped the list of 'buzzwords of the year 2020 ' selected by the authoritative language magazine Yaowen Jiaozi.

${ }^{92}$ Schneider and Hwang, 'The Sichuan earthquake'.
} 
purportedly 'hypocritical' human rights of the West through pun jokes such as 'wearing a mask, no human rights. not wearing a mask, no more humans' and the hashtag \#this is Chinese human rights\#. As mentioned earlier, the geopolitical and ideological lines along which the China versus the West binary is constructed are interlocking. It is believed that Western countries refuse to 'copy the homework' of China despite the obvious advantages of the China model because they are essentially biased towards the nation and determined to contain its global ascendancy. ${ }^{93}$

When the pandemic narratives became geopoliticised, domestic debates over governmental responses, accountability, and recognition of loss we have examined in earlier sections became distorted and delegitimated by a confrontational nationalism against the external threat. This is most evidently illustrated by the controversy around Fang Fang's Wuhan Diary, a series of blog posts documenting the life of ordinary people under lockdown in Wuhan while also calling for accountability. The journal was read by millions and received both acclaims and criticisms in the early stage of the crisis. However, public sentiments towards the Wuhan-based writer soon turned into an overwhelming deluge of hate after it became known that the diary was to be published in the US and Germany. As the tide turned, a massive, seemingly bottom-up campaign involving an enormous amount of ad hominem and misogynistic attacks were launched against her, who was accused of being a 'liar', a 'traitor' of her homeland, and handing a 'knife' to China's enemies for personal benefits. ${ }^{94}$ For the ultranationalists, the 'traitor' among 'us' seems to breed an even stronger hatred than the external enemy the 'traitor' is allegedly serving. In a telling example, a Weibo user under the name of 'Wuhan 520 association of volunteers' wrote a furious 'open letter' to 'Fang Fang and her likes': 'no matter how biased her articles are, domestically, it is her freedom. However, the moment when they are published abroad in such a humiliating way, we are no longer the same people!' They then characterised the publication of the diary for foreign audiences as plotting against the ' 1.4 billion people of China'. The letter also referred to moving stories of everyday heroism in the city and contrasted those 'ordinary heroes' with the ungrateful and unpatriotic writer. ${ }^{95}$ Although state actors do not appear to have directly steered the campaign, the censorship regime indirectly augments these views as criticisms and 'negative' sentiments against the government are much more likely to be censored, while posts that display intense hate and anger towards the external or internal enemy are left intact.

To conclude this section, it is important to stress that the imaginaries of geopolitical and ideological opposition between China and the West are globally produced through othering narratives from both sides that are complementary to each other. While the 'spectre of China' has played a part in 'reviving a nationalist political imagination' across the Atlantic, ${ }^{96}$ images of the West have loomed large in the configurations of Chinese pandemic nationalism as demonstrated above. The framing of the coronavirus crisis as a zero-sum game of winning or losing in terms of global influence and ideological competition is also prevalent in Western media discourse. The 'othering of the virus' as a racialised disease associated with backward practices and authoritarianism far away from the Global North in the early phase of the epidemic may have contributed to the lackadaisical responses to COVID-19 in Europe and the US in January and February 2020. ${ }^{97}$ An increasingly antagonistic view towards Beijing reflected in both official rhetoric and popular

\footnotetext{
${ }^{93}$ See, for instance, this post from a columnist for Guancha, a privately-owned news outlet that gathers the voice of China's most popular nationalistic opinion leaders, available at: $\{$ https://weibo.com/1887344341/IySgPBx29\}.

${ }^{94}$ Michael Berry, 'I translated "Wuhan Diary" to amplify the author's voice of courage', Washington Post (26 June 2020$)$, available at: $\{$ https://www.washingtonpost.com/opinions/2020/06/25/i-translated-wuhan-diary-amplify-authors-voice-courage/\}.

${ }^{95}$ Wuhan 520 Association of Volunteers, '写给方方们的话 [A letter to Fang Fang and her likes]' (16 April 2020), available at: $\{$ https://weibo.com/ttarticle/p/show?id=2309404494480056123396\}.

${ }^{96}$ James and Valluvan, 'Coronavirus conjuncture', p. 1238.

${ }^{97}$ Marius Meinhof, 'Othering the virus', Discover Society (21 March 2021), available at: \{https://archive.discoversociety.org/ 2020/03/21/othering-the-virus/\}.
} 
opinion polls in the West feeds into victimhood nationalism in China, ${ }^{98}$ fuels the emotional discontent with the Western hegemony in the international system among the Chinese public, and prompts more assertive diplomatic stances from the Chinese government. This in turn raises further the purchase power of the China threat discourse on the other side. The escalation of tensions between China and the US during the pandemic is rooted in pre-existing, mutually reinforcing dynamics through which one is constructed as a security threat, an economic competitor, and an ideological rival of the other. ${ }^{99}$ Politically motivated accusations and scapegoating in both nations serve to externalise domestic failures towards a foreign adversary and lead to a vicious circle of action and reaction.

\section{Epilogue: Struggles of memory}

If you cannot speak out loud, then be a whisperer. If you cannot be a whisperer, then be a silent person who remembers. ... Be a person with graves in the heart. ${ }^{100}$

At an MFA press conference in June 2020, Hua Chunying stated that the central government issued a White Paper on Chinese actions against COVID-19 'not to defend itself, but to record. Because pandemic narratives cannot be misled or stained by lies but should keep the correct collective memory'. However, the MFA's social media post on this statement inadvertently triggered a wave of sarcastic and discordant remarks. The top comments that gathered thousands of likes asked: "What is "correct"? Who has the power to define "correct" and why? What are they going to do with incorrect memories and people?' 'By the way any follow-ups on the Red Cross and the government vehicle scandals?' 'If my memory is not "correct" enough, may I ask if you will eliminate my memory or the bodily carrier of my memory?' These comments, as well as many of the posts under the hashtag \#incorrect collective memory\#, were soon removed from the platform. ${ }^{101}$ Although the celebratory and geopoliticised narrative that contrasts China's 'victory' over the pandemic with the failure of the Western other became prevalent and alternative accounts marginalised in the later phase of the pandemic, memories, after all, cannot be monopolised. Social media, despite the ever more restrictive repression of online speech, still provides a space for creatively protesting the state's efforts to erase and reshape memories.

Indeed, it would be difficult to envision these sporadic episodes of online resistance to have any significant impact on the political legitimacy the party state enjoys. ${ }^{102}$ However, the fact that memory activism has been brutally suppressed both online and offline also suggests the ultimate vulnerability of a powerful regime that fears the mere acts of recording censored news or mourning for the unrecorded deaths. Two volunteers working for a digital project hosted at Git-hub archiving censored articles about COVID-19 were arrested in April 2020 and later sentenced to jail. ${ }^{103}$ A citizen initiative named 'The Unrecorded', which collected information on COVID-19 deaths excluded from official statistics, was banned from Weibo in late February 2020 and has continued to maintain a crowdsourced digital archive outside the 'great firewall'

\footnotetext{
${ }^{98}$ 'Trump again defends use of the term "China virus"', CNN (19 March 2020), available at: \{https://edition.cnn.com/2020/ 03/17/politics/trump-china-coronavirus/index.html\}; Pew Research Center, 'Unfavourable Views of China Reach Historic Highs in Many Countries' (6 October 2020), available at: \{https://www.pewresearch.org/global/2020/10/06/unfavorableviews-of-china-reach-historic-highs-in-many-countries/\}.

${ }^{99}$ Oliver Turner, “Threatening” China and US security: The international politics of identity', Review of International Studies, 39:4 (2013), pp. 903-24.

${ }^{100}$ YAN Lianke, '經此疫劫, 讓我們成為有記性的人 [After this catastrophe, let us be those who remember]', The Initium (21 February 2020), available at: \{https://theinitium.com/article/20200221-mainland-coronavirus-yanlianke/\}.

${ }^{101}$ Screenshot archived in anonymous Telegram groups collecting censored social media posts.

${ }^{102}$ Liu, 'From social drama'.

${ }^{103}$ Guo Rui, 'Two Chinese activists sentenced to 15 months' jail for archiving censored internet material', South China Morning Post (13 August 2021), available at: \{https://www.scmp.com/news/china/politics/article/3144913/two-chinese-activists-sentenced-15-months-jail-archiving\}.
} 
of China. The initiative does not frame its objectives in explicitly political terms. Rather, the aim is that 'they should not be excluded from our mourning ... this is not to deny the efforts of the national battle against the pandemic, but only to let them not be forgotten. ${ }^{104}$ Despite its intentional distancing from 'politics', however, memory activisms such as this can be considered tacit forms of Antigonean mourning that challenge the state-sanctioned conditions of grievable life. The act of documenting unrecognised losses inevitably, even if implicitly, exposes unrecognised injustice, which makes it decisively political and thus potentially threatening to the political order.

Dr Li Wenliang's Weibo page presents another example of mundane, everyday commemoration that traverses the boundary between the private and the political. Numerous netizens have left messages on his Weibo page each day ever since his passing, and his last post has gathered more than one million comments. While the page was initially dubbed a 'wailing wall' as strangers gathered in this virtual space to mourn for the loss of $\mathrm{Dr} \mathrm{Li}$, it later turned into a 'tree hole' where internet users share their own private memories in an imagined conversation with the deceased and with each other. In their textual analysis of over one million comments, Baohua Zhou and Yuan Zhong note that April 2020 marked a turning point, after which 'accompanying' and 'confiding' gradually replaced grief and mourning to become the prevailing mode of communication in this 'extended affective space. ${ }^{105}$ In other words, it has transformed from a virtual community of mourning to one that documents and shares 'vernacular memories' of a nationalised tragedy. ${ }^{106}$ The vast majority of these messages tell private joys, anxieties, and aspirations in the daily lives of ordinary citizens. However, they also exhibit forms of sociality and publicness mediated by digital technology as commenters expect to be read by and communicate with others. Comments that directly concern the COVID-19 pandemic were typically posted in waves at the time point of certain events, such as the national mourning day and the meeting commending national role models in the fight against the pandemic. These may or may not challenge the official narratives of victory and patriotism: they may be 'telling' Dr Li proudly that 'we have won this war' or regretfully that 'although you were not at the commendation meeting today, you will always be in the people's heart'. ${ }^{107}$

The previous section has hinted at how pandemic narratives in China and the US are conditioned by and help construct the geopolitical and ideological rivalries between the two. While the Chinese government recognised Dr Li as a national 'martyr' and emphasised his identity as a CCP member, to the US senators who introduced a bill to rename the street outside the Chinese embassy in Washington, DC. 'Li Wenliang Plaza', he was a dissident who had been victimised by the 'cruelty and lies of the Chinese Communist Party'. ${ }^{108}$ The contestation over the meaning of deaths is ultimately about the contestation over the politics of the living. Without romanticising the extremely mundane and fragmented forms of memorialisation on Li's Weibo page, we might consider that the insistence on preserving private memories - which may or may not dispute the hegemonic stories of the nation - defies established categorisation and politicisations of life and death. Memories of trauma, as Edkins suggests, can be 'a mode of resistance to a language that forgets the essential vulnerability of flesh in its reification of state, nation and ideology'. ${ }^{109}$ The existence of a virtual public space for sharing private emotions and memories, no matter how trivial they may appear, potentially constitutes a form of digital

\footnotetext{
${ }^{104}$ The Unrecorded (31 May 2020), available at: $\{$ https://twitter.com/the_unrecorded/status/1267086072095232001\}.

${ }^{105}$ Baohua Zhou and Yuan Zhong, “春天的花开秋天的风” : 社交媒体、集体悼念与延展性情感空间 [“Spring flowers and autumn winds": Social media, collective mourning, and extended affective space]', Chinese Journal of Journalism and Communication, 43:3 (2021).

${ }^{106}$ Aaron Hess, 'In digital remembrance: Vernacular memory and the rhetorical construction of web memorials', Media, Culture and Society, 29:5 (2007), pp. 812-30.

${ }^{107}$ Zhou and Zhong, 'Spring flowers'.

${ }^{108}$ US Senator Ben Sasse press release (7 May 2020), available at: $\{$ https://www.sasse.senate.gov/public/index.cfm/2020/5/ bill-renames-chinese-embassy-street-li-wenliang-plaza\}.

${ }^{109}$ Edkins, 'Remembering relationality', p. 100.
} 
resistance to the 'correct collective memory' sovereign power seeks to define. However, this is also contrasted with how strictly policed commemorative activities at Li's physical grave are. From the perspective of authorities, this virtual space of alternative memorialisation is tolerated may be precisely due to that it has been neutralised, trivialised, and therefore depoliticised.

\section{Conclusion}

On 1 June 2020, People's Daily posted an English-language video with the following script:

This is China, temporarily locking down one city for the safety of the whole country. This is also China, determinedly using the strength of the whole country to save one city. This is China, grieving all the deceased. This is also China, saving lives at all costs. ... This is China, which has been questioned, vilified and smeared. This is also China, which conveys goodwill, responsibility and confidence. This is China, which has been hit hard by the cold winter. This is also China, which has ushered in the rebirth of a warm spring.

It concludes with a quote from President Xi Jinping: 'for thousands of years, the Chinese nation has experienced many ordeals, but none of them has defeated us. In the end, they elevated our national spirit, will and strength over and again. ${ }^{, 10}$ The video, featuring sentimental images and an inspirational soundtrack, perfectly summarises the repertoire of disaster nationalism examined in this article. I have explicated how long-established threads of disaster nationalist discourse in contemporary China have been digitally restyled and contested with a focus on the politics of emotion. While the state has sought to transform a crisis into resources for enhancing national identity and political legitimacy through appropriating grief, mobilising gandong, and encouraging antagonistic sentiment towards the enemy, social media has allowed for a limited space for alternative expressions of grief, rage, and critical solidarity as well as sharing vernacular memories of a nationalised tragedy. Emphasising the uncertainties and indeterminacy in the operation of disaster nationalism and its contestations, I have also scrutinised the ways in which popular narratives affectively internalise or reinscribe dominant ideas about the (inter)national community: such as the historical imagination of a continuous nationhood rising from disasters and humiliations, positive energy, and a dichotomous view of the international order characterised by Western hegemony and Chinese victimhood. The geopoliticisation of the pandemic, which is rooted in and exacerbating pre-existing tensions between China and the West, has shaped the external dimension of Chinese narratives of COVID-19. This is to be understood within globally entangled discursive and material processes, in which forces of antagonistic nationalism on different sides of the geopolitical fault line feed into each other by co-producing binary oppositions between the self and the other. While this article is focused on the dynamics of digital disaster nationalism in the Chinese context, the pervasiveness of emotional political communication in the age of social media and the intensification of nationalism in times of crisis are broader global trends across democratic and authoritarian regimes. Future research may explore these phenomena comparatively and investigate in more depth how Chinese and Western discourses of self and other in international politics interact and entangle with one another.

Supplementary material. To view the supplementary material for this article, please visit: \{https://doi.org/10.1017/ S0260210522000018\}

Acknowledgements. I would like to thank the RIS editors and reviewers for their insightful criticisms and suggestions. Earlier versions of this article were presented at the Trinity Centre for Asian Studies, the European Institute for Chinese Studies, and the 'Citizenship in Pandemic Times' conference. I would like to thank Isabella Jackson, Eric Florence, and Sophia Woodman for the kind invitation and the audiences for their engagement. Exchanges with Ting Guo, Carwyn

${ }^{110}$ People's Daily (1 June 2020), available at: \{https://weibo.com/2803301701/J4EiG6hPK\}. 
Morris, Kailing Xie, and Dechun Zhang helped improve my thinking on these issues. This piece is a humble tribute to the lives lost to the pandemic, recorded and unrecorded, and those who have put themselves at risk to tell the story.

Chenchen Zhang is a lecturer in politics and international relations at Queen's University Belfast. Author's Twitter profile: @chenchenzh

Cite this article: Zhang, C. 2022. Contested disaster nationalism in the digital age: Emotional registers and geopolitical imaginaries in COVID-19 narratives on Chinese social media. Review of International Studies 48, 219-242. https://doi.org/ $10.1017 /$ S0260210522000018 